Ю. О. Гончарова

\title{
ОСОБЛИВОСТІ ГРАМАТИЧНИХ КАТЕГОРІЙ УКРАЇНСЬКОЇ МОВИ (НА МАТЕРІАЛІ ГРАМАТИК 20 - 30-Х РР. ХХ СТ.)
}

\begin{abstract}
Гончарова Ю. О. Особливості граматичних категорій української мови (на матеріалі граматик 20 - 30-х рр. ХХ ст.).

У статті визначено характерні особливості основних іменних і дієслівних граматичних категорій української мови, зафіксовані в українських граматиках 20 - 30-х рр. XX ст., порівняно з російською. Узагальнено головні причини та засоби вираження міжмовних відмінностей на граматичному рівні.

Ключові слова: граматична категорія, грамема, категорія роду, категорія числа, категорія відмінка, категорія часу, категорія способу, категорія стану.
\end{abstract}

Гончарова Ю. О. Особенности грамматических категорий украинского языка (на материале грамматик $20-30-\mathrm{x}$ гг. XX в.).

В статье выделены характерные особенности основных именных и глагольных грамматических категорий украинского языка, которіе зафиксированны в украинских грамматиках $20-30-\mathrm{x}$ гг. XX в., в сравнении с русским. Определены главные причины и средства выражения межязыковых отличий на грамматическом уровне.

Ключевые слова: грамматическая категория, грамема, категория рода, категория числа, категория падежа, категория времени, категория способа, категория залога.

Goncharova J. O. The grammatical categories peculiarities of the Ukrainian language (on the grammars material of the $20-30^{\text {th }}$ of the $\mathrm{XX}^{\text {th }}$ century).

The article deals with the features of the main grammatical categories of the Ukrainian language, fixed in the Ukrainian grammars of the $20-30^{\text {th }}$ of the $\mathrm{XX}^{\text {th }}$ century, in comparison with the Russian. The basic causes and the means of expression of the language differences were summarized on the grammatical level.

Key words: grammatical category, grammeme, category of gender, category of number, category of case, category of mode, category of voice.

Сучасне мовознавство має дискусійний характер. Значна кількість науково-практичних проблем залишаються відкритими для наукового пошуку. Привертають до себе увагу й граматичні категорії української мови, особливо в контексті варіантності та неусталеності їх граматичних форм. Таке становище провокує порушення норм на всіх мовних рівнях. 
Тому вдосконалення граматичної структури мови, зокрема узагальненої граматичними категоріями системи граматичних форм, відіграє важливу роль для поліпшення мовної ситуації в цілому. Неодностайність поглядів лінгвістів на граматичні процеси та явища, перевага непідвладної нормам практики над приписами теорії, розмитість ролі державної мови в суспільному та побутовому житті громадян - неповний перелік причин і досі несистематичного та орфографічно недовершеного функціонування української мови.

Неабиякою перепоною для формування гармонійного та природного мовленнєвого простору українців, як відомо, $\epsilon$ повсякчасний $i$ цілеспрямований вплив російського мовлення. Це спричиняє збіднення та спотворення як української, так і російської мовної свідомості. В умовах так званого білінгвізму, що не контрольований жодними державними інстанціями, явище змішування та інтерференції є закономірним. 3 огляду на історичну долю української мови, що зазнала значного радикального впливу спорідненої російської мови, питання чистоти та природності побутування потребує невідкладних та не менш радикальних заходів. Отже, звертаючи увагу на окремішність української мови, особливості іiі граматичної структури, глибоко вкоріненої в національну психологію сприймання дійсності, та акцентування на відмінності однієї мови від іншої, а саме: української від російської, $-\epsilon$ одним із кроків на шляху до перемоги над мовленнєвим україно-російським хаосом.

Одним із джерел удосконалення системи граматичних категорій української мови $є$ праці видатних мовознавців $20-30-x$ рр. ХХ ст.: О. Курило, В. Сімовича, О. Синявського, М. Сулими та ін. У часи українізації, коли написано основоположні українські граматики, склалися якнайсприятливіші умови для кодифікації мовних норм української мови. Не важко помітити, розглядаючи історію творення українського мовознавства, що його розвиток не має закономірного та поступового плину - акумулювання ідей 3 подальшим їх узагальненням. Історія української науки про мову більше нагадує біг з перепонами. Як результат - ідеї граматистів 20 - 30-х рр. ХХ ст. наразі $є$ не менш актуальними, ніж 80 років тому. Після пережитої мовою «чистки на мовному фронті» $[4$, с. $34-38 ; 10$, с. $113-132 ; 13$, с. 174;] радянською системою фундаментальна частина сучасного знання про мову базується на національно свідомих позиціях знаних лінгвістів перших десятиліть $\mathrm{XX}$ ст. Зважаючи на це, їхні грунтовні дослідження, на нашу думку, $\epsilon$ актуальними, важливими та необхідними. Окрім того, врахування досвіду українських граматистів 20 - 30-х рр. щодо особливостей граматичних категорій української мови має цілком практичне значення - поширення правильних та питомо українських граматичних форм.

Мета даної розвідки - на матеріалі граматик українських мовознавців 20 - 30-х рр. ХХ ст. окреслити найвиразніші риси та 
особливості основних граматичних категорій, зважаючи на характерні відмінності від російських категорій, на причини цих відмінностей та засоби їх вираження.

Однією 3 найавторитетніших сучасних праць у галузі теоретичної граматики є «Теоретична морфологія української мови» I. Р. Вихованця та К. Г. Городенської [2], де зреалізовано функціонально-категорійний підхід. Автори ставили на меті обгрунтувати сукупність морфологічних одиниць $і$ типів морфологічних категорій та парадигм, а також висвітлити функціонування морфологічних одиниць і категорій, зв'язків морфології 3 синтаксисом і словотвором [2, с. 6]. Не менш важливою з цього погляду $є$ праця М. Я. Плющ «Граматика української мови. Морфеміка. Словотвір. Морфологія», у якій представлено традиційний підхід із урахуванням нових тенденцій категорійної граматики [5, с. 3]. Крізь призму культури мови характерні граматичні особливості висвітлено у працях О. Пономаріва «Культура слова: Мовностилістичні поради» [6] та Б. Д. Антоненка-Давидовича «Як ми говоримо» [1]. Показово, що багато сформульованих сучасними дослідниками мовностилістичних порад відображено й у граматиках $20-30-\mathrm{x}$ р. ХХ ст., що свідчить про актуальність багатьох поглядів граматистів перших десятиліть XX ст.

Характеризуючи внесок мовознавців 20 - 30-х pp. ХХ ст., Ю. Шевельов зазначає: «Праця етнографічної школи була дуже корисна, поскільки вона виявляла національні питоменності української мови і виводила на світло денне чуже, позбавлене коріння й грунту» [12, с. 14]. За словами мовознавця, О. Синявський та М. Сулима, найвизначніші нормалізатори української літературної мови, намагалися критично переосмислити традиції народної мови крізь призму перспектив майбутнього розвитку, роблячи ставку на творення європейської української літературної мови [12, с. 14-15].

О. С. Черемська, розглядаючи проблему дерусифікації в працях мовознавців 20 - 30-х рр. XX ст., наголошує на тому, що саме після появи визначних дослідників 20 - 30-х рр , праці яких справили «тривалий вплив на розвиток української мови» [11, с. 193], вперше гостро постало «питання про руйнівний вплив російської мови на українську мовну систему» $[11$, с. 190]. Отже, визначаючи місце української мови серед інших слов'янських, зокрема порівнюючи морфологічні та синтаксичні особливості української й російської мов, варто звернутися до праць українських граматистів $20-30-\mathrm{x} \mathrm{pp.} \mathrm{XX} \mathrm{ст.}$

$\mathrm{У}$ нашому дослідженні для аналізу та виявлення відмінностей 3 російською мовою ми обрали іменні категорії роду, числа й відмінка та дієслівні категорії часу, способу і стану. Виокремлюючи особливості категорій, кожній із них надано відповідну назву. В основному назви складаються 3 двох означуваних слів, перше 3 яких характеризує засіб вираження міжмовних відмінностей (тобто чим ті чи інші одиниці мови 
відрізняються в українській та російській мовах), а друге - причину цих відмінностей (тобто чому, на основі чого одиниці відмінні між собою).

Причинами відмінностей між граматичними категоріями української та російської мов, на нашу думку, є такі: семантична - існує через різне сприйняття дійсності мовцями або через функціонування тих чи інших граматичних форм лише для певних семантичних значень; грамемна виокремлена на основі наявності або відсутності певної грамеми в одній із двох мов; словотвірна - відмінність процесів словотвору в ході історичного розвитку мов; частотна, що характеризується пріоритетністю певної конструкції для однієї з мов, та синтаксична, що означає відмінність типів синтаксичного зв'язку (керування). Засобами вираження особливостей граматичних категорій є: формальний - мовні одиниці відрізняються формою (флексія, основа, аналітичність / синтетичність тощо); частотний - переважання конструкцій в одній із двох мов; словотвірний - відмінність виділяється на основі словотвірних формантів; та морфологічний, виділений на основі використання різних частин мови для передачі одного змісту.

Словотвірно-семантична особливість категорії роду української мови полягає в тому, що, на відміну від російської мови, як зазначає М. Сулима, українські слова на позначення посади, професії, звання, рангу розмежовують за статтю за допомогою суфіксації - додавання суфікса -к, наприклад: автор - авторка, композитор - композиторка, лікар лікарка [9, с. 11]. М. Сулима зауважує, що «професійні чоловічі назви, опріч свого спеціально-чоловічого значіння, мають ще й загальну силу, характеризуючи всіх людей якоїсь професії чи стану без огляду на натуральний рід, на стать. А жіночі назви мають завжди обмежене, специфічно-жіноче значіння» [9, с. 12]. «Отже значення чоловічих назв ширше, а жіночі назви - індивідуалізовані, обмежені на змісті» [9, с. 8]. Така питома особливість має давнє походження. Схильність української мови до фемінізації слів на позначення занять людини, на нашу думку, відображає, з одного боку, особливо поважливе ставлення українців до осіб жіночої статі, а з іншого, соціальну значимість жінок в українському суспільстві. Багато слів в українській та російській мовах мають різний рід, наприклад: відпустка (в укр. - жін., у рос. - чол.), картопля (в укр. - жін., у рос. - чол.), біль (в укр. - чол., у рос. - жін.), посуд (в укр. - чол., у рос. жін.) тощо [9, с. 8]. Хоч це явище обумовлене традицією.

Категорію числа в українській мові порівняно 3 російською характеризують частотна та формально-семантична особливості. Явище вживання слів, що не мають значення збірності, в однині замість множини у стилістиці має назву синекдохи. М. Сулима зазначає, що «однина таких слів означає іноді або явище, що раз-у-раз трапляється, або цілу низку істот чи речей - неодмінно однакових, чимсь подібних одне до одного, наприклад: Од Лимана до Трубайла трупом поле крилось (Т. Шевченко)» 
[9, с. 20]. Мовознавець наголошує на тому, що синекдоха в українській мові вживається частіше, ніж, скажімо, у російській чи білоруській $[9$, c. 20]. Це й дозволяе нам говорити про існування частотної особливості категорії числа.

В. Сімович у «Практичній граматиці української мови», характеризуючи типи зв'язків у простому реченні, звертає увагу на традиційну для української мови числову неузгодженість між підметом i присудком, коли підмет стоїть в однині, а присудок - у множині. Насамперед, це стосується звертання та заочної розмови про батьків або про близьких поважних людей, наприклад: Мама йдуть, батько нездужають, баба лають, пан-отещь прийшли $і$ т. ін. [8, с. 385]. 3 огляду на сферу побутування даної особливості граматичної категорії числа та той факт, що сам граматист називає таке явище «складнею за думкою, не граматичною» [8, с. 464], виокремлюємо іiі як формально-семантичну. Дослідник зауважує, що в російській та німецькій мові відсутнє «викання» у звертанні до батьків, що, на його думку, через історико-політичні обставини негативно вплинуло і на традиційне звертання українців. Щодо думки М. Сулими, то науковець називає таке вживання множини, яке дуже поширене в народі, «пошанною множиною» і лише вказує на іiі західноєвропейське походження. Мовознавець, насамперед, наголошує на формі множини звертань-займенників та залежних від них означень, не виокремлюючи традиційного українського звертання до батьків, наприклад: Що бо ви, пане сотнику, оце говорите? (І. КвіткаОснов'яненко); Мамо, мамусю, чому не їсте? (П. Тичина); Ви такі веселі були вчора $[9$, с. 22].

Стосовно особливостей категорії роду та категорії числа в українській мові можна говорити про їх вихід за межі лінгвістичного рівня мови, оскільки вони яскраво відображають світоглядні якості українців.

Категорія відмінка в українській мові складається з семи грамемвідмінків, деякі з яких мають свої характерні особливості, відмінні від відповідної грамеми в російській мові.

Досліджуючи граматики 20 - 30-х рр. ХХ ст. ми виявили, що грамема називного відмінка має кілька питомих відмінностей. М. Сулима зазначає, що вживання називного присудкового становить «одно 3 найхарактеристичніших явищ в українській мові» [9, с. 30]. Дієслівною частиною може бути дієслово-зв'язка $\epsilon$, допоміжне дієслово бути та його форми 3 модальними дієсловами, а також дієприкметник бувши [9, с. 29-30]. Наприклад: Латин і серием і душею далекий бувши од війни,.. таку сказав річ старшинам (І. Котляревський) [9, с. 29]. Зважаючи на зазначене, можна виокремити частотну особливість грамеми називного відмінка, адже акцент падає на формальний вибір та різницю в частоті функціонування пріоритетних форм. 
I М. Сулима, й О. Курило, покликаючись на О. Потебню, наголошують на тому, що вживання в називному відмінку іменної частини складеного присудка для української мови - частіше, притаманніше та архаїчніше, ніж вживання орудного відмінка в цьому випадку, як у російській та польській мовах [9, с. 30; 3, с. 94]. Наприклад: Вони були найрозумніші люди свого часу Кул. VI, 502 [3, с. 94]. Хоч граматисти й не заперечують можливість паралельного функціонування обох конструкцій і в українській мові. О. Курило, узагальнюючи випадки вживання української народної мови, робить висновок про те, що «в інструменталі виражена неістотна, змінна ознака; у номінативі може бути виражена i істотна, незмінна, і неістотна, змінна, ознака...» [3, с. 93-94]. Отже, мова йде про формально-семантичну особливість називного відмінка, оскільки граматисти виокремлюють іiі на основі переваги під час вибору тієї чи іншої форми залежно від відтінків у значенні в обох мовах.

Грамемі родового відмінка в українській мові, на нашу думку, притаманні кілька функціонально-семантичних особливостей. В. Сімович, розкриваючи палітру значень родового відмінка в українській мові, зауважує існування характерного лише для неї, на відміну від російської, значення часу родового відмінка, що в реченні разом із залежним прикметником виконує функцію обставини, наприклад: Кожного ранку й вечора виходила з хати старенька жінка (Мирний) [8, с. 469]. Оскільки для родового відмінка російської мови не властиво позначати час i виконувати функцію обставини, ми кваліфікуємо дану особливість як формально-семантичну. Варто зазначити, що, на жаль, у сучасному українському, особливо усному, мовленні трапляються систематичні порушення законів національного синтаксису, зокрема вживання на позначення часу, за аналогією до російської мови, знахідного відмінка 3 прийменником. Наприклад: на наступний рік, а треба - наступного року, на минулому тижні, а треба - минулого тижня.

О. Курило наполягає на неприродності для української мови конструкції іменника 3 родовим відмінком на позначення належності, наприклад: твори Шевченка, теорія Дарвіна, гніздо птахів тощо, пропонуючи заміняти їх конструкціями на зразок: Шевченкові твори, Дарвінова теорія, пташине гніздо [3, с. 156-157]. Хоч дослідниця й не виключає випадків використання конструкції з родовим, коли треба повідомити про декілька об'єктів належності (твори Шевченка, Куліша, $\Phi р а н к а)$, коли прикметник може бути важкий для вимови (твори КвіткиОснов'яненка), коли об'єктом належності є повне ім'я (поезія Tараса Шевченка) або від нього вже є залежний прикметник [3, с. 157]. Цікаво, що натомість О. Синявський застерігає від надуживання конструкцій 3 прикметниками належності замість конструкцій з родовим відмінком, наголошуючи на тому, що «по-перше, такі словосполучення доречні тільки тоді, коли прикметник походить від назви живої істоти і майже виключно 
особи, а по-друге, коли іменниковий член пари визначає те, що належить особі, передусім річ, далі й властивість іiі, діяльність, напр.: братова шапка, Кулішева вдача, Шевченкові переконання. Але краще сказати похорон Шевченка, значіння Франка тощо, бо ж тут уже належности, присвійности немає, а є лише стосунок, дальший і інший зв'язок певних явищ і речей» [7, с. 232]. Граматист розмежовує ступінь конкретизації в двох конструкціях, окреслюючи конструкцію 3 родовим належності як предметнішу, а конструкцію 3 прикметником як абстрактнішу (у тих випадках, коли прикметник не присвійний) [7, с. 235]. Нам здається, що позиція О. Синявського більш обгрунтована, ніж позиція О. Курило, хоч кожний випадок має бути розглянутий з різних боків до прийняття рішення. Зважаючи на важливість семантичного наповнення належності та неусталеність позицій мовознавців $20-30-\mathrm{xp}$. ХХ ст. вищеописана особливість грамеми родового відмінка, на нашу думку, $є$ формально-семантичною.

Грамемі родового відмінка певних слів української мови відповідно до українських граматик 20 - 30-х рр. ХX ст. притаманна ще одна формально-семантична особливість. О. Курило вказує на відмінність між російською та українською мовами у вживанні відмінків після інфінітива деяких перехідних дієслів, зокрема: вчитися, доглядати, чекати, чути, зазнавати, вживати, вишукувати, просити тощо [3, с. 105-108]. Дослідниця звертає увагу на те, що власне українською конструкцією $є$ інфінітив з родовим відмінком, на відміну від російської, де із зазначеними дієсловами вживають знахідний. Наприклад: Як заграє московщини, на всю Польщу чути Чуб. V, 469 [3, с. 106]. Крім того, можливе відмінне від російської мови вживання родового відмінка поряд iз іншими конструкціями 3 деякими прикметниками: близький, винен, голодний, жадний, заздрісний, свідомий, иікавий тощо [3, с. 142]. Наприклад: Близький смерти, божевілля. Благородні хліба голодні. Ном. 953. Жадний помсти (і - Я на гроші не жадний НКл. 34) [3, с. 142]. У російській мові в згаданих конструкціях родовий відмінок не вживають.

Грамемі знахідного відмінка притаманна формально-синтаксична особливість. Так, В. Сімович наголошує на необхідності вживати поряд зі словами на зразок: зрадити, зраджувати - лише знахідний відмінок об'єкта, на відміну від російської мови, де вживають давальний відмінок [8, с. 474]. Активне використання сьогодні неправильної з погляду національного синтаксису конструкції зраджувати кому ще раз доводить актуальність наукових позицій українських мовознавців $20-30-x$ рр. ХХ ст.

Грамема орудного відмінка, на нашу думку, має дві особливості: частотно-семантичну та формально-семантичну. М. Сулима та О. Курило наголошують на тому, що, на відміну від російської, для української мови вживання слів на позначення дійової особи в орудному відмінку 3 дієсловами та дієприкметниками пасивного стану, а також з дієсловами на -но, -то не характерне [9, с. 39; 3, с. 55]. Наприклад: Це подано ним до 
відома. Ним видаються книжки [9, с. 55]; Ця земля була викуплена нашими ще дідами [9, с. 39]. Дослідники радять такі конструкції перетворювати на активні, або на місці орудного відмінка діяча, активно вживаного в російській мові, використовувати родовий відмінок 3 прийменником від, наприклад: Ти янгол від Бога присланий, щзоб мене пожалувати Кв. [3, с. 56]. Що ж до дієслів на -но, -то, як зауважує О. Курило, вживання слів на позначення діяча в структурі безпідметового речення взагалі недоречне, оскільки це суперечить його логічній структурі - «в дієприслівникові-присудкові лежить поняття хтось зробив» $[3$, с. 55]. Натомість О. Синявський, найвидатніший нормалізатор української літературної мови 20 - 30-х рр. ХХ ст., заперечує безоглядне вилучення з ужитку орудного діяча 3 пасивних конструкцій, наголошуючи на семантичній невідповідності конструкцій 3 орудним та родовим відмінками. Граматист застерігає від безпідставної та легковажної «українізації», тобто штучного протиставлення синтаксису української мови російському, адже це може призвести до скалічення змісту комунікативних одиниць [7, с. 250-257], наприклад: Завойована від Польщі людність [7, с. 256] (складається враження, що в Польщі відвоювали частину людей, а не навпаки). Що ж до дієслів на -но, -то, мовознавець і тут не заперечує синтаксичної сполучуваності 3 ними орудного діяча [7, с. 253]. Частотно-семантична особливість грамеми орудного відмінка на позначення дійової особи є дискусійною. Чіткіше окреслено лише позицію орудного діяча при дієсловах на -но, -то, де форма орудного відмінка на позначення дійової особи логічно неможлива.

Більшість граматистів (О. Курило, В. Сімович, М. Сулима, О. Синявський) одностайні в тому, що необхідно вживати орудний відмінок саме на позначення знаряддя дії. 3 дієсловами на зразок: говорити, читати, писати, перекладати, вчити, навчати [3, с. 124; 8 , с. $477 ; 9$, с. $39 ; 7$, с. 258$]$, - синтаксично сполучуваний орудний відмінок іменника мова, що називає знаряддя, наприклад: Поучали з иерковної амвони рідних братів чужою мовою Гр. [3, с. 124]; Радюк говорив чистою украӥнською мовою (І. Нечуй-Левицький) [9, с. 39]. А тому варіант говорити на украӥнській мові за альтернативою з російською (говорить на русском языке) - неправильний. Так само знаряддям $\epsilon$ засоби пересування та передачі інформації, наприклад: передавати поштою, а не передавати по пошті, плисти кораблем, а не плисти на кораблі, їхати кіньми, а не їхати на конях [8, с. 477-478; 9, с. 39; 3, с. 128]. Характерним для української мови, як зазначає О. Синявський, на відміну від російської мови, є й орудний місця: іти вулицею, лісом, иляхом [7, с. 258]. На жаль, згадані поради, що характеризують формально-семантичну особливість грамеми орудного відмінка української мови, й досі не враховано належним чином. 
У російській граматичній системі кличного відмінка, на відміну від української, немає. Отже, мова йде про формально-грамемну особливість. В. Сімович заперечує виокремлення в граматиці української мови звертання, називаючи такий підхід «окремою обговіркою», «бо ж по формі вже пізнати кличник» [8, с. 476-477]. На нашу думку, виділення звертання поряд із кличним відмінком не $є$ тавтологією, адже ці поняття стосуються різних рівнів граматичної системи: морфологічного, коли говоримо про кличний відмінок іменника, та рівня синтаксичної структури речення, у якому, виокремлюючи звертання, визначаємо місце іменника у кличному відмінку.

Дієслівну категорію часу, на нашу думку, також характеризують певні особливості, засвідчені вже в українських граматиках 20 - 30-х рр. ХХ ст. М. Сулима [9, с. 64] та О. Курило [3, с. 82] вважають активне вживання в українській мові передминулого часу, що може бути як дійсного, так i умовного способу, однією 3 найхарактерніших іiі особливостей порівняно 3 іншими східнослов'янськими мовами. Наприклад: Я почав був читати июю книжку, а потім облишив ї̈ та й заснув; Пропав би був вівчар та визволив комар (Л. Глібов) [9, с. 64-65]. М. Сулима зауважує, що в білоруській мові грамема передминулого часу особливо не виокремлюються, у російській форми передминулого часу вживаються ще рідше $[9$, с. 66]. Граматисти закликають не плутати російських конструкцій 3 было, невластивих українській мові, 3 українськими формами передминулого часу [3, с. 82; 9, с. 66-67], наприклад: Хотел было читать, но помешали [3, с. 82]. Зважаючи на те, що мова йде про виокремлення грамеми передминулого часу та іï поширеність в обох мовах, ми говоримо про існування формальнограмемної особливості. Форма передминулого часу дуже поширена і в сучасній народній українській мові.

Грамемі майбутнього часу властива формально-словотвірна особливість, суть якої полягає в існуванні поряд з аналітичною формою майбутнього часу недоконаного виду традиційно української синтетичної форми, що утворилася злиттям інфінітива головного дієслова та форм теперішнього часу дієслова няти (-му, -меш, -ме, -мемо(-мем), мете, -муть), наприклад: Що ж ти робитимеш, синку, на чужій стороні? - Як жсивий буду, землю оратиму, рибальством жситиму (М. Коцюбинський) [9, с. 68]. На цьому наголошували М. Сулима [9, с. 68], В. Сімович [8, с. 277-278] та О. Синявський [7, с. 78-79]. О. Синявський зазначає, що «злиті форми недоконаного майбутнього часу... в літературній мові поширеніші, ніж з буду, будещ» [7, с. 79]. У сучасному мовленні часто невмотивовано надуживають конструкціями $36 y \partial y$, скоріше від незнання формальних пріоритетів.

Категорія способу в українській мові має яскраву формальнословотвірну особливість, що стосується грамеми наказового способу. 
О. Курило та М. Сулима звертають увагу на власне українську форму дієслова першої особи множини із старовинним закінченням -iм, імо, -ймо, якій немає відповідників у російській мові [3, с. 86-87; 9, с. 6972], наприклад: Що там замазувать! Кажкімо правду! (Л. Українка) [9, c. 69]. Це ще раз підтверджує глибинну відмінність, хоч і споріднених, української та російської мов, що відображено як на граматичному, так і на психологічному рівнях.

Граматична категорія стану в українській мові, що наразі є однією 3 найдискусійніших, відрізняється від російської категорії стану. Морфологічно-грамемна особливість, на нашу думку, полягає в тому, що категорійна опозиція «активність - пасивність» не повністю представлена в українській мові, на відміну від російської. Так, О. Курило, М. Сулима, О. Синявський одностайно заперечують існування в українській мові активних дієприкметників на -чий, -(в)щий [3, с. 18; 9, с. 72; 7, с. 96-100]. Наприклад: Тварини, жсиючі й жсивші на землі. Факт, спостерігаємий [3, с. 18]. Дослідники звертають увагу на притаманні українській мові конструкції, які використовують у випадках, коли в російській мові вживають дієприкметники активного стану. На відміну від російської мови, що дуже активно використовує активні дієприкметники, у граматичній структурі української мови таких утворень немає. М. Сулима пояснює використання чужих морфем результатом впливу російської та польської мов і відповідних граматик, що були поширені в підневільній Україні [9, с. 74]. О. Синявський звертає увагу на те, що українська літературна мова має тенденцію до втрати дієприкметниковості та розвитку нових способів висловити думку [7, с. 100]. За словами В. Сімовича, «страждального стану (пасивного) українська мова не любить, радо його обминає» [8, с. 282]. Отже, дієприкметнику, як особливій формі дієслова, категорія стану притаманна лише як синтаксична характеристика конструкцій, до складу яких входять дієприкметники. У такому випадку, на нашу думку, доречно говорити про пасивність дієприкметників, утворених від перехідних дієслів, як про їх неодмінну якість, не протиставляючи їм активність як грамему, а лише як протилежний спосіб висловлювати думку.

М. Сулима зазначає, що для народної мови вживання пасивного («переємного») стану не $\epsilon$ характерним, на відміну від літературної [9, с. 77], що свідчить про існування частотно-семантичної особливості української категорії стану, адже, скажімо, у науковому стилі досить часто вживають пасивні конструкції, аргументуючи тим, що акцент падає на об'єкт, а не на суб'єкт дослідження. О. Курило в «Увагах до сучасної української літературної мови» говорить, що «українські дієсловаприсудки на -ся мають у підметових фразах здебільшого значіння активне. I взагалі українські дієслова на -ся здебільшого активного, а не пасивного 
значіння» [3, с. 87]. Дослідниця радить якомога менше вживати пасивних дієслів на -ся, тобто лише у тих випадках, коли без них не можна обійтися.

Категорія стану в українській мові як морфологічна категорія представлена лише фрагментарно: дієслова здебільшого активні (синтаксична прихильність мови до активного значення), дієприкметники ж в українській мові набагато ближчі до прикметників через повну відсутність активності в їх парадигмі. Так, К. Г. Городенська категорію стану в українській мові визначає як морфолого-словотвірно-синтаксичну [2, с. 242], тобто таку, що не обмежується для свого повного категорійного вияву лише одним морфологічним рівнем. Загалом же категорія стану української мови є однією 3 найвиразніших характеристик граматичного ладу мови порівняно з іншими слов'янськими мовами.

Причини та засоби вираження відмінностей між граматичними категоріями української та російської мов можна подати у вигляді таблиці.

Таблиия 1

\begin{tabular}{|c|c|c|c|c|c|}
\hline Причини & $\begin{array}{c}\text { Семантична } \\
\text { Засоби }\end{array}$ & $\begin{array}{c}\text { Грамемна } \\
3\end{array}$ & $\begin{array}{c}\text { Словотвірна } \\
2\end{array}$ & $\begin{array}{c}\text { Частотна } \\
2\end{array}$ & $\begin{array}{c}\text { Синтаксична } \\
1\end{array}$ \\
\hline $\begin{array}{c}\text { Формальний } \\
11\end{array}$ & ++++++ & ++ & ++ & & + \\
\hline $\begin{array}{c}\text { Частотний } \\
4\end{array}$ & ++ & & & ++ & \\
\hline $\begin{array}{c}\text { Словотвірний } \\
1\end{array}$ & + & + & & & \\
\hline $\begin{array}{c}\text { Морфологічний } \\
1\end{array}$ & & & & & \\
\hline
\end{tabular}

Серед причин відмінностей кількісно переважає семантична причина, що свідчить про абсолютно різні способи мислення та механізми сприймання дійсності українців і росіян та відбиття їх у граматичній системі мови. Щодо засобів вираження характерних особливостей граматичних категорій української мови, то домінує формальний засіб, що, у свою чергу, $\epsilon$ найяскравішим матеріальним виявом міжмовної відмінності та підгрунтям для порівняння. 3 таблиці видно, що такі причини відмінностей, як: грамемна, словотвірна, частотна, синтаксична, виявляють себе набагато рідше, ніж семантична. Водночас маємо малу кількість інших засобів вияву типових рис, таких як: частотний, словотвірний та морфологічний. Усе це наочно доводить тісну спорідненість багатьох рівнів української та російської мов: морфологічного, словотвірного, синтаксичного та стильового. Адже основна причина відмінностей, що найчастіше виявлять себе формально, лежить у народній психології, національному світогляді та ментальності.

Отже, дослідивши українські граматики 20 - 30-х рр. ХХ ст., ми виявили, що основні граматичні категорії української мови (роду, числа, 
відмінка, часу, способу та стану) мають ряд характерних особливостей. Для кожної з них встановлено причину, на якій грунтується виникнення міжмовних відмінностей, та засіб вираження цих відмінностей. Найпоширенішими серед них є формально-семантичні особливості, тобто такі, що виникли на основі семантичної розбіжності в українській та російській мовах й виражені формально. Це свідчить про природну окремішність народних світопочувань. Зважаючи на складну мовну ситуацію в країні, де надто відчутний вплив російської мови, важливо наголошувати на відмінностях обох мов з метою збереження їх чистоти.

\section{Література}

1. Антоненко-Давидович Б. Д. Як ми говоримо / Б. Д. Антоненко-Давидович. - К. : Либідь, 1991. -253 с.

2.Вихованець І. Р. Теоретична морфологія української мови : Академ. Граматика укр. мови / I. Р. Вихованець, К. Г. Городенська; [За ред. І. Р. Вихованця]. - К. : Унів. вид-во «Пульсари», 2004. - 400 с.

3.Курило О. Уваги до сучасної української літературної мови / О. Курило. - [2-ге вид.]. - К. : Видво Соломії Павличко «Основи», 2008. - 303 с.

4. Масенко Л. Мова і суспільство. Постколоніальний вимір / Л. Масенко. - К. : Вид. дім «КиєвоМогилянська акад.», 2004. - 162 с.

5.Плющ М. Я. Граматика української мови. Морфеміка. Словотвір. Морфологія : [підручник] : у 2-х ч. - Ч. 1 / М. Я. Плющ. - К. : Вища школа, 2005. - 286 с.

6.Пономарів О. Культура слова : Мовностилістичні поради [навч. посібник]. - [2-ге вид., стереотип] / О. Пономарів. - К. : Либідь, 2001. - 240 с.

7.Синявський О. Н. Норми української літературної мови / О. Н. Синявський. - Львів : Українське видавництво, 1941. - 363 с.

8.Сімович В. І. Граматика української мови для самонавчання в допомогу шкільній науці / В. І. Сімович. - Мюнхен : Український вільний університет, 1986. - 584 с.

9.Сулима М. Українська фраза : коротенькі начерки / М. Сулима. - Харків : Харківська школа друкарського діла ім. А. Багинського тресту «Харків-друк», 1928. - 99 с.

10. Українська мова у XX сторіччі : історія лінгвоциту : [док. і матеріали] / [упорядкув. Л. Масенко та ін.]. - К. : Вид. дім «Києво-Могилянська акад.», 2005. - 339 с.

11. Черемська О. С. Проблема дерусифікації української мови в працях мовознавців 20 - 30-х рр. ХХ ст. / О. С. Черемська // Вісник Харківського національного університету. - Харків : ХНУ, 2000. № 491. - С. 190-193.

12. Шевельов Ю. В. Портрети українських мовознавців / Ю. В. Шевельов. - К. : Вид. дім «КиєвоМогилянська академія», 2002. - 132 с.

13. Шевельов Ю. В. Українська мова в першій половині двадцятого століття $(1900-1941)$ : стан і статус / Ю. В. Шевельов. - Чернівці : «Рута», 1998. - 207 с. 